Cornell Law Library

Scholarship@Cornell Law: A Digital Repository

Cornell Law Faculty Publications

Faculty Scholarship

$12-1-2001$

\title{
Inside the Black Box: Comment on Diamond and Vidmar
}

Valerie P. Hans

Cornell Law School, valerie.hans@cornell.edu

Follow this and additional works at: http://scholarship.law.cornell.edu/facpub

Part of the Civil Procedure Commons, Insurance Law Commons, Legal Writing and Research Commons, and the Litigation Commons

\section{Recommended Citation}

Hans, Valerie P., "Inside the Black Box: Comment on Diamond and Vidmar" (2001). Cornell Law Faculty Publications. Paper 314. http://scholarship.law.cornell.edu/facpub/314

This Article is brought to you for free and open access by the Faculty Scholarship at Scholarship@Cornell Law: A Digital Repository. It has been accepted for inclusion in Cornell Law Faculty Publications by an authorized administrator of Scholarship@Cornell Law: A Digital Repository. For more information, please contact jmp8@cornell.edu. 
INSIDE THE BLACK BOX: COMMENT ON DIAMOND AND VIDMAR

\section{Valerie P. Hans ${ }^{*}$}

TT is an honor to be invited to comment on the first publication of 1 the Arizona Jury Project, a study of Arizona juries that includes videotaping and analysis of jury room discussions and deliberations. ${ }^{1}$ It is a remarkable and unique project, made possible by an unusual confluence of people, places, and events. In an insightful opinion some years ago, United States Supreme Court Justice Louis Brandeis observed that "[i]t is one of the happy incidents of the federal system that a single courageous State may, if its citizens choose, serve as a laboratory; and try novel social and economic experiments without risk to the rest of the country."2 The state of Arizona has taken just such a bold path in experimenting with its jury system.

Guided by the leadership of its judiciary and enabled by the openness of its legal practitioners, Arizona has been at the forefront of jury reform. An Arizona Supreme Court committee headed by Judge B. Michael Dann published an influential report in 1994, Jurors: The Power of 12, proposing a host of changes to the state's jury system. ${ }^{3}$ Most of these recommended changes were adopted. What is more, the judiciary and state bar have welcomed social scientific research on how these changes affect the jury system, providing the country with a living laboratory for jury reform.

The scientific merit of the Arizona Jury Project was enhanced by the readiness of two of the nation's top sociolegal scholars, Profes-

* Professor of Sociology and Criminal Justice, University of Delaware; Visiting Scholar and Adjunct Professor, University of Pennsylvania Law School, 2000-01.

This article was prepared for the conference, "New Perspectives on Evidence," sponsored by the University of Virginia School of Law, The John M. Olin Program in Law and Economics, and the Virginia Law Review, February 24, 2001. I wish to thank B. Michael Dann, Paula Hannaford, and G. Thomas Munsterman for helpful comments on an earlier draft.

'Shari Seidman Diamond \& Neil Vidmar, Jury Room Ruminations on Forbidden Topics, 87 Va. L. Rev. 1857 (2001).

${ }^{2}$ New State Ice Co. v. Liebmann, 285 U.S. 262, 311 (1932) (Brandeis, J., dissenting).

${ }^{3}$ Arizona Supreme Court Committee on More Effective Use of Juries, Jurors: The Power of 12 (1994) [hereinafter Arizona Supreme Court Committee]. 
sors Shari Seidman Diamond and Neil Vidmar, to serve as research directors. These two scholars have long inspired me with their zest for social science study of the law. This enthusiasm, coupled with the high quality of their research and writing, has led to many impressive research contributions. ${ }^{4}$ The Arizona Jury Project promises to be another major achievement for both of these scholars and a significant milestone in the study of the American jury.

Many benefits are sure to come from looking inside the black box of jury decisionmaking. By examining what goes on in the jury room in a systematic way, Diamond and Vidmar will help us to assess whether current theories and empirical conclusions about juror and jury decisionmaking, based on indirect research methods, apply to actual jury decisions. They can help us determine whether legal rules, such as the evidence rules they examine in their paper in this symposium, adequately guide the jury process. They can assess how jury reform works in Arizona and thus provide significant information to policymakers contemplating change.

In this article, I will explore the potential contributions of the Arizona Jury Project. After a discussion of the project's design and the unique methodological challenges faced by the researchers, I will assess their observations about how jurors deal with the forbidden topic of insurance. ${ }^{5}$ I will then consider their suggested reform, and the collaborative instructional approach they advocate.

${ }^{4}$ Shari Seidman Diamond's work spans three decades and includes many influential articles on jury research. E.g., Shari Seidman Diamond, Simulation: Does the Microscope Lens Distort?, 3 Law \& Hum. Behav. 1 (1979); Shari Seidman Diamond \& Judith N. Levi, Improving decisions on death by revising and testing jury instructions, 79 Judicature 224 (1996); Hans Zeisel \& Shari Seidman Diamond, "Convincing Empirical Evidence" on the Six-Member Jury, 41 U. Chi. L. Rev. 281 (1974); Hans Zeisel \& Shari Seidman Diamond, The Effect of Peremptory Challenges on Jury and Verdict: An Experiment in a Federal District Court, 30 Stan. L. Rev. 491 (1978).

Neil Vidmar's research and writing on the jury includes numerous articles and three books: Valerie P. Hans \& Neil Vidmar, Judging the Jury (1986); Neil Vidmar, Medical Malpractice and the American Jury: Confronting the Myths about Jury Incompetence, Deep Pockets, and Outrageous Damage Awards (1995); and World Jury Systems (Neil Vidmar ed., 2000).

Both Diamond and Vidmar conduct research on other sociolegal topics as well, including dispute resolution, the psychology of retribution, trademark infringement, and sentencing.

${ }^{5}$ My paper is based on Diamond and Vidmar's original manuscript, which focused on the jury's treatment of insurance. Their revised paper also examines the jury's treatment of another forbidden topic: attorney's fees. Time did not permit me to 


\section{THE ARIZONA JURy PROJECT: STUDY DESIGN AND METHODOLOGICAL CHALLENGES}

The Arizona Jury Project, which includes analysis of actual jury discussions and deliberations, will allow us to take a close look at how the fundamental jury reforms enacted in Arizona operate in context. Several of these jury reforms constitute a significant departure from the adversarial model of the trial, which presumes a passive decisionmaker and adversaries who develop the evidence in the case. ${ }^{6}$ In contrast to the adversary tradition of the passive decisionmaker, the Arizona jurors studied in this project are able to take notes, ask questions of witnesses, and discuss the evidence as the trial goes along.

The Arizona Jury Project also promises to make a unique methodological contribution to the field of jury studies. Up to this point, virtually all of the scientific research on the American jury has been done using indirect research methods. These have included interviewing jurors after their service,' administering post-trial questionnaires, ${ }^{8}$ analyzing jury verdicts, ${ }^{9}$ and conducting mock jury research in the laboratory. ${ }^{10}$ Using these research methods, jury scholars have developed a number of theories and conclusions

revise my paper to include analysis of this additional material. My own research, though, supports Diamond and Vidmar's discovery that civil juries frequently discuss attorney's fees in deliberating on awards. Nicole L. Mott, Valerie P. Hans \& Lindsay Simpson, What's Half a Lung Worth? Civil Jurors' Accounts of Their Award Decision Making, 24 Law \& Hum. Behav. 401, 411 (2000) (finding that $85 \%$ of civil juries reported discussing attorney's fees in award discussions).

'Stephan Landsman, The Adversary System: A Description and Defense 2-3 (1984).

${ }^{7}$ William J. Bowers, The Capital Jury Project: Rationale, Design, and Preview of Early Findings, 70 Ind. L.J. 1043, 1077 (1995).

${ }^{*}$ Harry Kalven, Jr. \& Hans Zeisel, The American Jury, at vi (1966).

${ }^{9}$ Kevin M. Clermont \& Theodore Eisenberg, Do Case Outcomes Really Reveal Anything About the Legal System? Win Rates and Removal Jurisdiction, 83 Cornell L. Rev. 581, 581 (1998); Brian J. Ostrom et al., A step above anecdote: a profile of the civil jury in the 1990s, 79 Judicature 233, 233 \& n.1 (1996).

${ }^{10}$ Brian H. Bornstein, The Ecological Validity of Jury Simulations: Is the Jury Still Out?, 23 Law \& Hum. Behav. 75, 76 (1999); Shari Seidman Diamond, Illuminations and Shadows from Jury Simulations, 21 Law \& Hum. Behav. 561 (1997). 
about the American jury. ${ }^{11}$ Policymakers have relied on this research to suggest jury reforms. ${ }^{12}$

In the Arizona Jury Project, we can now gauge for the first time the extent to which knowledge derived from direct observations of jurors during the trial and the deliberations converges with knowledge obtained from other sources. The fact that the Arizona Jury Project videotaped jury trial proceedings is arguably just as important as its novel videotaping of jury discussions and deliberations. Few, if any, studies to date have recorded all of the information available to jurors at the trial as well as the jurors' response to that information within the same research project. In terms of the data available about what nearly four hundred jurors saw and did in these fifty cases, the project goes far beyond any previous jury research. Diamond and Vidmar have an unparalleled opportunity to report on a contextually rich examination of the jury at work.

To be sure, this real-world research presented substantial methodological challenges. In the ivory tower's scientific laboratories, investigators can screen, control, and modify the information made available to study participants. For example, the impact of certain evidence, such as a defendant's insurance, can be manipulated experimentally. ${ }^{13}$ Some participants are randomly assigned to hear a case with the evidence, while others are randomly assigned to a control condition. Using random assignment helps to ensure the comparability of participants in the two conditions, so that statistical differences in the responses of the two groups of participants can be traced to the impact of insurance information.

Jury researchers who leave their laboratories to study jury decisionmaking in the courtroom often must adapt ideal procedures to real world settings and cope with unforeseen circumstances or de-

"For summaries of the research, see Hans \& Vidmar, supra note 4; Inside the juror: The psychology of juror decision making (Reid Hastie ed., 1993); Verdict: Assessing the Civil Jury System 341 (Robert E. Litan ed., 1993).

${ }^{12}$ See, e.g., Council for Court Excellence, Juries for the Year 2000 and Beyond: Proposals to Improve the Jury Systems in Washington, DC (1998); Arizona Supreme Court Committee, supra note 3; Hon. B. Michael Dann, "Learning Lessons" and "Speaking Rights": Creating Educated and Democratic Juries, 68 Ind. L.J. 1229 (1993).

${ }^{13}$ Dale Broeder and his colleagues from the Chicago Jury Project undertook such a study in the 1950s. Dale W. Broeder, The University of Chicago Jury Project, $38 \mathrm{Neb}$. L. Rev. 744, 753-55 (1959). 
mands. For example, in two field experiments with actual civil juries undertaken by the National Center for State Courts ("NCSC") in the $1990 \mathrm{~s}$, one on jury size ${ }^{14}$ and the other on trial discussions, ${ }^{15}$ problems arose in the random assignment of cases to experimental conditions. In the jury size experiment, civil cases were randomly assigned to be heard by either eight- or twelve-person juries during the study period. ${ }^{16}$ To accommodate the jury trial rights of litigants and to overcome the objections of the bar, however, the research design allowed attorneys whose cases were assigned to the eightperson jury to have it heard by a twelve-person jury instead. ${ }^{17} \mathrm{~A}$ significant number of attorneys chose to do so. Analyses revealed that the set of cases in which attorneys refused to follow the random assignment was quite distinctive. ${ }^{18}$ As a group, the cases were relatively weak ones, but they were vigorously contested. The refusal cases were more likely to result in defense verdicts and smaller awards, but plaintiffs sued for larger damages, sued more defendants, called more expert witnesses, and spent more time on jury selection. ${ }^{19}$ The distinctive nature of these cases made it difficult to assess the independent effects of jury size on some dimensions such as win rate and award variability.

In the NCSC Trial Discussions field experiment, the study procedure randomly assigned civil jury trials to either a "Trial Discussions" or a "No Trial Discussions" group. ${ }^{20}$ In the Trial Discussions condition, civil jurors could discuss the evidence during the trial, as is current practice in Arizona civil trials. In the No Trial Discussions condition, they were admonished to wait until the end of the trial to discuss the evidence with other jurors, the common practice elsewhere. Apparently by chance, however, the random assignment resulted in noncomparable cases in Pima County. Trial

${ }^{14} \mathrm{G}$. Thomas Munsterman et al., A Comparison of the Performance of Eight- and Twelve-Person Juries (1990).

15 Paula L. Hannaford et al., Permitting Jury Discussions During Trial: Impact of the Arizona Reform, 24 Law \& Hum. Behav. 359 (2000); Valerie P. Hans et al., The Arizona Jury Reform Permitting Civil Jury Trial Discussions: The Views of Trial Participants, Judges, and Jurors, 32 U. Mich. J.L. Reform 349, 365 (1999).

${ }^{16}$ Munsterman et al., supra note 14, at 18-19.

${ }^{17}$ Id. at 21.

${ }^{18}$ Id. at 22.

${ }^{19}$ Id. at 23-24 \& tbl.2.

${ }^{20}$ Hannaford et al., supra note 15 , at 363; Hans et al., supra note 15, at 365. 
judges who presided over the cases rated the evidence in the Trial Discussions cases as much more likely to favor the plaintiff, compared to the ratings of their colleagues who presided over the No Trial Discussions cases. ${ }^{21}$

The Arizona Jury Project reflects some of the understandable decisions and methodological compromises Diamond and Vidmar made in study design. Perhaps the most significant challenge is that the Arizona Jury Project consists of cases that are self-selected. That is, the jurors, the attorneys and parties, and the judge were all informed of the taping procedure and agreed to participate in the study. The surreptitious tape-recording of a handful of jury deliberations by the Chicago Jury Project during the $1950 \mathrm{~s}^{22}$ was ethically questionable and would violate contemporary research standards. Diamond and Vidmar took the ethically sound approach of full disclosure. Contemporary standards for the treatment of research participants require this type of disclosure, including potential benefits and harms, under most circumstances. To inform trial participants and jurors and to obtain their agreement to participate was desirable and perhaps even essential. We must assess, however, the extent to which this set of self-selected jurors and cases are comparable to all Pima County cases, and the degree to which they are able to reflect typical jury behavior across a wide spectrum of trials.

Diamond and Vidmar report some encouraging statistics about the level of juror participation. They estimate that more than $95 \%$ of the jurors who reported to jury duty in Pima County agreed to be in the project. ${ }^{23}$ Attorneys and litigants, however, were less apt to agree to have their cases be included in the research project.

This raises the question of what reasons might lead attorneys and litigants to participate in the study. In particular, are they or their cases similar or different from the rest of the caseload? Recall the jury size study in California, in which civil trial attorneys whose

${ }^{21}$ In Pima County, cases heard by Trial Discussions juries were more likely to result in plaintiff victories than cases heard by juries who could not discuss the evidence. Hannaford et al., supra note 15 , at 368 . Without the judicial ratings, we might have concluded that the trial discussions themselves created a pro-plaintiff tilt among jurors.

${ }^{2}$ Kalven \& Zeisel, supra note 8, at vi-vii.

${ }^{23}$ Diamond \& Vidmar, supra note 1, at 1870. 
cases were hotly contested were more apt to refuse the random assignment to a smaller jury. For a 1997 CBS production, Enter the Jury Room, trials and jury deliberations in four Arizona criminal trials were taped with the consent of the parties, attorneys, and jurors. ${ }^{24}$ Two of the three cases in which everyone agreed to be videotaped resulted in hung jury outcomes. ${ }^{25}$ The curious prevalence of hung jury outcomes (rare in Arizona) suggests at a minimum that the cases in which all parties agreed to be taped were unusual. It hints that the sense of both attorneys that they had a fighting chance might be a factor.

Diamond and Vidmar report one way in which the study cases appear to be different from cases in other jurisdictions: The proportion of cases won by plaintiffs is higher in the Arizona Jury Project trials than the plaintiff win rate in a national study of urban courts. ${ }^{26}$ In the Arizona Jury Project, plaintiffs won $65 \%$ of the time. The plaintiff win rate for automobile cases was even higher, at $76 \%{ }^{27}$

Close examination of the Pima County data from the national study and from other research, however, suggests that Pima County plaintiff win rates are somewhat higher than the national average. The comparison also shows an increase during the 1990s in Pima County plaintiff win rates.

Table 1 compares the Arizona Jury Project win rate with the win rates from several other projects. ${ }^{28}$

${ }^{24}$ CBS News: Enter the Jury Room (CBS television broadcast, April 1997). For an interesting perspective from the program's producer, see David Schneider, Jury Deliberations and the Need for Jury Reform: An Outsider's View, 36 Judges' J. 23 (1997).

${ }^{25}$ CBS News producer David Schneider reported that they gained access to three different cases. In the first case that CBS taped, the jury hung, and CBS returned three months later to cover the retrial, in which a new jury convicted the defendant. A second case resulted in a conviction. The third case CBS taped was a retrial from a prior trial in which the jury hung. The retrial also resulted in a hung jury. Schneider, supra note 24 , at 24 .

${ }_{26}$ They compare their $65 \%$ win rate to the $49 \%$ overall win rate in tort cases in a 1992 national study conducted by the NCSC and the Bureau of Justice Statistics. Diamond \& Vidmar, supra note 1, at 1872 \& n.54; see also Ostrom et al., supra note 9.

${ }^{27}$ Diamond \& Vidmar, supra note 1 , at 1872 \& n.54.

${ }^{28}$ Table 1 reports data from several different sources. National data from the NCSC/BJS 1992 study were provided in Ostrom et al., supra note 9, at 235 fig. 4.1992 data for Pima County were obtained through analysis of the 1992 state court database, State Court Civil Jury Trials (1997), at http://teddy.law.cornell.edu:8090/questtrs.htm 
Table 1. A Comparison of Plaintiff Win Rates in Jury Trials.

\begin{tabular}{|l|c|c|c|}
\hline \multicolumn{1}{|c|}{ Study } & $\begin{array}{c}\text { Overall } \\
\text { Win Rate }\end{array}$ & $\begin{array}{c}\text { Win Rate in } \\
\text { Automobile } \\
\text { Cases }\end{array}$ & $\begin{array}{c}\text { Total } \\
\text { Number } \\
\text { of Cases }\end{array}$ \\
\hline $\begin{array}{l}\text { NCSC/BJS National } \\
\text { Study of Jury Trials } \\
(1992)\end{array}$ & $49 \%$ & $60 \%$ & 9,522 \\
\hline $\begin{array}{l}\text { NCSC/BJS Pima } \\
\text { County Jury Trials } \\
(1992)\end{array}$ & $50 \%$ & $63 \%$ & 78 \\
\hline $\begin{array}{l}\text { NCSC/BJS National } \\
\text { Study of Jury Trials } \\
(1996)\end{array}$ & $49 \%$ & $57 \%$ & 10,616 \\
\hline $\begin{array}{l}\text { NCSC/BJS Pima } \\
\text { County Jury Trials } \\
(1996)\end{array}$ & $62 \%$ & $75 \%$ & 79 \\
\hline $\begin{array}{l}\text { NCSC Trial Discus- } \\
\text { sions Study, Pima } \\
\text { County Jury Trials } \\
(1997-98)\end{array}$ & $64 \%$ & $72 \%$ & 64 \\
\hline Arizona Jury Project & $65 \%$ & $76 \%$ & 50 \\
\hline
\end{tabular}

In 1992, Brian Ostrom and his colleagues found that nationwide, plaintiffs won $49 \%$ of their cases. ${ }^{29}$ The win rate in Pima County jury trials in 1992 was $50 \%$, which included a $63 \%$ win rate for automobile torts. ${ }^{30}$ By 1996 , although the national win rate stayed about the same, Pima County plaintiffs won $62 \%$ of their cases before juries, including $75 \%$ of automobile jury trials. Similarly, in the NCSC Trial Discussions Study, which collected data in Pima County during 1997 and 1998, Pima County juries found for the

(1997). Data for the NCSC/BJS 1996 national study were reported in Carol J. DeFrances \& Marika F.X. Litras, Civil Trial Cases and Verdicts in Large Counties, 1996, Bureau of Justice Statistics Bulletin, September 1999, available at http://www.ojp.usdoj.gov/bjs/pub/pdf/ctcvlc96.pdf. Paula Hannaford of NCSC provided me with 1996 Pima County win rates in automobile jury trials. Telephone Interview with Paula Hannaford, Senior Research Associate and Staff Attorney, NCSC (June 4, 2001). I analyzed data from the NCSC Trial Discussions Study for Table 1.

${ }^{29}$ Ostrom et al., supra note 9, at 235 fig. 4.

${ }^{30}$ State Court Civil Jury Trials, supra note 28. 
plaintiff $64 \%$ of the time. The win rate in the plentiful automobile tort cases $(61 \%$ of the NCSC Pima jury trials involved automobile torts) was $72 \%$.

These recent Pima County win rates are very close to those in the Arizona Jury Project. This suggests that the high win rate of cases in the Arizona Jury Project sample accurately reflects Pima County jury trials, rather than constituting evidence of biased case selection. The relatively high Pima County win rates in the late 1990s are intriguing, leading me to wonder whether there have been some legal or procedural changes that could account for the apparent increase.

Diamond and Vidmar speculate that the Pima County practice of a trial de novo after a disputed arbitration skews the sample of jury trials toward strong plaintiff cases. ${ }^{31}$ It is an interesting possibility, and reminds us that what might look at first like a case selection problem or even jury behavior might be the product of other processes at work. ${ }^{32}$

The other methodological issue that deserves mention is the possibility that jurors and other legal actors might modify their behavior when they are being videotaped. Diamond and Vidmar say they have no reason to believe that the videotaping affected juror behavior, citing research evidence that the effect of videotaping on interactive behavior dissipates quickly, and the jurors in their study displayed behavior that they presumably would not want to become public. ${ }^{33}$ The jury trial provides a unique context, however, in that the judge announces specific expectations about juror roles and behavior throughout the trial, highlighting and reinforcing juror concerns about social desirability during their discussions and deliberations. It is probably safest to assume that the Arizona Jury Project's observations of forbidden topics in this study are likely to underestimate the typical extent of discussion in juries that are not being videotaped.

"Diamond \& Vidmar, supra note 1, at 1872 n.54.

32 Vidmar makes the point that jury verdict statistics can mislead observers. A high plaintiff win rate, for example, may tell us more about settlement practices in a specific jurisdiction than about juror behavior. Neil Vidmar, Pap and Circumstance: What Jury Verdict Statistics Can Tell Us About Jury Behavior and the Tort System, 28 Suffolk U. L. Rev. 1205, 1216-17 (1994); see also Clermont \& Eisenberg, supra note 9 (discussing the problem of relying on case outcomes to infer jury behavior).

${ }^{33}$ Diamond \& Vidmar, supra note 1, at 1870 n.49. 


\section{JURORS AND INSURANCE: FINDINGS OF THE ARIZONA JURY PROJECT}

The Diamond and Vidmar article gives us an impressive preview of the Arizona Jury Project's broad potential to generate profound insights into jury behavior. Through painstaking analysis of the jury trial and deliberation recordings, Diamond and Vidmar make several very interesting discoveries about the role of insurance in jury trials. The first discovery, made possible because the trials themselves were recorded in full, is that witnesses often mention insurance during trial. ${ }^{34}$ From one perspective, that's not surprising. Many civil cases involve accidents and injuries. Most people in the normal course of events talk about insurance when discussing accidental injury and medical treatment. Under Arizona law, however, the introduction of insurance is prohibited under most circumstances. ${ }^{35}$ Legal commentators justify the rule with the concern that if jurors learn about the presence or absence of insurance they will give it inappropriate consideration. ${ }^{36}$

The second finding is that in the vast majority of jury deliberations $(85 \%)$, there was at least a passing mention of either the defendant's or the plaintiff's insurance. ${ }^{37}$ Jurors discussed insurance on average four times during deliberations. ${ }^{38}$ The deliberation analysis suggested that, in a significant number of these cases, the jury deliberation reflected the trial testimony about insurance and may have been affected by it. ${ }^{39}$ In other cases, jurors introduced the topic spontaneously. ${ }^{40}$ Jurors asked the judge questions about insurance in more than a quarter of the cases in the sample. ${ }^{41}$

${ }^{34}$ Id. at 1876.

${ }^{35}$ Id. at $1875-76$.

${ }^{36}$ The commentary to Federal Rule of Evidence 411 (stating that evidence that a person was or was not insured is not admissible in determining liability) notes that "if the jurors hear about insurance coverage, or the lack of it, they may decide the case on the basis of the deepest pocket, rather than on the facts." Fed. R. Evid. 411 advisory committee's note.

${ }^{37}$ Diamond \& Vidmar, supra note 1, at 1876.

${ }^{38}$ Id.

${ }^{39}$ Id. at $1877,1880$.

${ }^{40}$ Id. at 1884.

${ }^{41} \mathrm{Id}$. at 1885 . In a Ph.D. dissertation on case complexity and civil juries, Nicole Mott analyzed juror questions in cases of the NCSC Trial Discussions Study. Nicole L. Mott, How Civil Jurors Cope with Complexity: Defining the Issues (2001) (unpublished Ph.D. dissertation, University of Delaware). When possible, trial judges 
The ability to observe juror discussions directly is especially valuable in dealing with the forbidden topic of insurance. It might be expected that other methods, such as post-trial questionnaires or interviews, would underestimate the frequency of discussions about issues that juries are told not to consider. To explore this, I compared the frequency of juror discussions of insurance in the Arizona Jury Project to the results of my own research using posttrial juror interviews in cases with business and corporate defendants. ${ }^{42}$ In my study, I asked civil jurors who decided cases with business and corporate parties whether insurance was a factor in how they thought about the case or their award discussions. ${ }^{43} \mathrm{Al}-$ though there are differences in the two groups of cases, it is an excellent opportunity to contrast the divergent methodologies of direct observation and post-trial interviews.

The proportion of jurors in my study who recalled discussing insurance during award discussions was lower than the percentage of Arizona Jury Project deliberations in which insurance was mentioned. In my study, slightly over a third of the juries who found for the plaintiff said that they discussed the defendant's insurance in the process of arriving at an award. ${ }^{44}$ About one out of five juries said they had discussed whether or not the plaintiff's insurance covered any amount. ${ }^{45}$ Therefore, jurors reported to me that there was some consideration of insurance in award discussions less than half the time. ${ }^{46}$ If we compare that number to the $82 \%$ in the Arizona Jury Project, the interview method as expected underestimates the extent to which insurance is discussed in the black box of the jury room.

The types of comments made by jurors from the Arizona Jury Project and my interview study of business jury trials overlapped.

included the text of juror questions along with completed questionnaires as part of the research project. Questions about insurance were infrequent. They constituted just $3 \%$ of the juror questions from the Trial Discussions Study. Id. at 136 tbl. 5.1. It is possible that judges in the NCSC study neglected to turn in a disproportionate number of juror questions about insurance, or that in the Arizona Jury Project cases there was an unusually strong degree of juror interest in insurance.

${ }^{42}$ Valerie P. Hans, Business on Trial: The Civil Jury and Corporate Responsibility (2000).

${ }^{43}$ Id. at 197.

4 Id. at 199.

${ }^{45} \mathrm{Id}$.

${ }^{46}$ Id.; Mott et al., supra note 5 , at 403. 
In both projects, jurors speculate about the defendant's coverage, but at the same time express great interest in learning about and discussing the plaintiff's insurance coverage. ${ }^{47}$ Both studies reveal some hostility to the idea that plaintiffs could receive a windfall jury award for medical expenses that have already been covered through insurance. ${ }^{48}$ Both projects also show that jurors draw on their own experiences and presuppositions about insurance to try to assess whether or not the parties are fully covered by insurance. ${ }^{49}$

Diamond and Vidmar observe that insurance is discussed primarily in award deliberations rather than in liability assessments. ${ }^{50}$ In my interview study, I also found that jurors concentrated on insurance mostly in discussing how much to award the plaintiff. ${ }^{51}$ However, for two reasons, it is plausible that the impact of insurance might also affect a jury's liability verdict. First, the lines between the two legally distinct judgments of liability and award amount can blur together as individual jurors decide the case. Second, insurance might affect a defense juror's willingness to engage in compromise verdicts. In compromise verdicts, a juror who favors the defense compromises with other jurors who favor the plaintiff, exchanging a liability verdict for a lower award.

One juror I interviewed told me that he assumed that the defendant had insurance, and that the award was not coming out of the defendant's pocket. Asked how it would have been different if it had come directly from the defendant, the juror replied, "I don't know, I might've fought harder when I was on the jury to see if we could ask the judge questions or bring in more evidence." ${ }^{, 52}$ A juror in a medical malpractice trial confided that the relevance of insurance had been debated by the other jurors, and asserted: "I felt that whether they had insurance or didn't have insurance wasn't a reason to decide the case for which way." 53 These examples hint that insurance might not be neatly cabined in the award discussions but might also spill over into liability issues.

${ }^{47}$ Diamond \& Vidmar, supra note 1, at 1889; Hans, supra note 42, at 199-201.

${ }^{48}$ Diamond \& Vidmar, supra note 1, at 1889; Hans, supra note 42, at 200.

${ }^{49}$ Diamond \& Vidmar, supra note 1, at 1878-79, 1884, 1890-91; Hans, supra note 42 , at $200-01$.

${ }^{50}$ Diamond \& Vidmar, supra note 1, at 1889.

${ }^{51}$ Hans, supra note 42 , at 200-03.

52 Id. at 203.

${ }^{53}$ Id. at 204. 
Diamond and Vidmar conclude that insurance has few implications for story construction. ${ }^{54} \mathrm{I}$ disagree. Possession of insurance coverage is associated with positive attributes, reflecting the conscientiousness and social responsibility of individual or business parties. In my study, most jurors assumed that business defendants had insurance to cover the costs of accidents, which suggests that failure to have insurance would be seen as a departure from the norm. ${ }^{55}$ Negative inferences about the character, integrity, and responsibility of uninsured motorists, doctors, and companies are likely.

\section{DIAMOND AND VIDMAR'S PROPOSED JURY REFORM: THE COLLABORATIVE INSTRUCTION ABOUT INSURANCE}

Whether discussions about insurance pertain to the plaintiff's or the defendant's coverage, Diamond and Vidmar observe that they introduce inappropriate and sometimes mistaken considerations into the deliberations. ${ }^{56}$ Currently, jurors who ask questions about insurance are admonished by the judge to disregard it. In theory, they are blindfolded about insurance matters, which ideally will promote their decisionmaking on the basis of the relevant evidence in the case. Diamond and Vidmar, however, make a convincing argument that the traditional blindfolding approach cannot succeed. ${ }^{57}$ Indeed, the Arizona Jury Project data provide a compelling testament to its inadequacy.

In light of the nearly ubiquitous discussion of insurance in jury deliberations documented by the Arizona Jury Project;' Diamond and Vidmar suggest revising the traditional blindfolding approach that courts have taken in dealing with the issue to date. In formulating a recommended instruction, they draw on recent research in social cognition and decisionmaking, which shows that jurors, like the rest of us, take an active approach to the decisionmaking task..$^{58}$

\footnotetext{
4 Diamond \& Vidmar, supra note 1, at 1879.

s Hans, supra note 42 , at 213.

". Diamond \& Vidmar, supra note 1, at 1884.

${ }^{57}$ Id. at $1905-07$.

${ }^{\circledR}$ Susan T. Fiske \& Shelley E. Taylor, Social Cognition (1984); Reid Hastie, The Role of "Stories" in Civil Jury Judgments, 32 U. Mich. J.L. Reform 227 (1999); Nancy Pennington \& Reid Hastie, Evidence Evaluation in Complex Decision Making, $51 \mathrm{~J}$. Personality \& Soc. Psychol. 242 (1986); Nancy Pennington \& Reid Hastie, Explaining
} 
Acknowledging that jurors are likely to speculate actively about insurance matters, their proposed instruction to disregard insurance takes a more reasoned approach. The instruction notes that the law does not allow parties to present information about insurance coverage. However, it then attempts to discourage juror exchange of misinformation and speculation by pointing out that "some plaintiffs are covered and some are not, and some have various forms of partial coverage. The same is true for defendants.... [T] [insurance coverage]."

The collaborative thrust of the instruction, in which jurors are treated as colleagues rather than underlings who are not to be trusted, is very attractive. I think the reasoning part of the instruction could be more fully developed, using the approach that Diamond and her colleague Professor Jonathan Casper adopted in a research project on the trebling provision in antitrust cases. ${ }^{60}$ Diamond and Casper tested several different ways of informing jurors about the trebling provision in antitrust jury awards. Admonitions to disregard trebling were not effective unless they were paired with an explanation of the reasons for the trebling. ${ }^{61}$ Taking a similar approach, the current version of the proposed insurance instruction could be expanded to provide the various justifications for excluding insurance information, helping to explain to the jury why it must decide the case without that seemingly pertinent knowledge. This expansion would enhance the collaborative quality of the instruction.

Like Diamond and Vidmar, I would value an empirical study of the impact of such an instruction, perhaps using mock jury methodology. Mock jurors would decide the same case, but some would be told nothing about insurance, others would be given a traditional admonition to disregard insurance in assessing the case, and

the Evidence: Tests of the Story Model for Juror Decision Making, 62 J. Personality \& Soc. Psychol. 189 (1992); Nancy Pennington \& Reid Hastie, The Story Model for Juror Decision Making, in Inside the juror, supra note 11, at 192.

${ }^{59}$ Diamond \& Vidmar, supra note 1, at 1910.

${ }^{60}$ Shari Seidman Diamond \& Jonathan D. Casper, Blindfolding the Jury to Verdict Consequences: Damages, Experts, and the Civil Jury, 26 Law \& Soc'y Rev. 513, 52124 (1992).

${ }^{61}$ Id. at 534. 
still others would hear one or more versions of the reasoned collaborative instruction about insurance.

Properly designed, the experiment might also provide an opportunity to learn what difference it makes if jurors hear specific information about a plaintiff's or defendant's insurance coverage. Despite the ubiquity of insurance discussions among civil jurors, and the possibility that insurance might affect inferences about the defendant's and plaintiff's character, story construction, and liability, I would not be surprised to discover that informing jurors about insurance coverage makes little difference in their verdicts or awards. Several experimental studies of the deep pockets effect, in which jurors are purported to be affected by the financial wealth of the defendant, have found no impact of defendant wealth on decisionmaking. ${ }^{62}$ If insurance did have an impact, I would expect it to be strongest in cases of severe injury where an award would have a catastrophic impact on an uninsured defendant. ${ }^{63}$

\section{CONCLUSION}

The Arizona Jury Project promises to fulfill Justice Brandeis's observation that courageous states that experiment with legal reform will generate substantial and broad-ranging benefits. As a demonstration study of the active jury model, the Project can teach us whether trial procedures that are more cognizant of jurors' strengths and predispositions promote juror decisionmaking quality in civil trials. It can also speak to concerns expressed by some scholars and litigators that jury reforms that encourage a more active role on the part of the decisionmaker could generate some negative consequences. For example, Professor Joseph Sanders observes that many recent jury reforms weaken the adversaries' control over the case, whether it is by increasing the judge's role (through case management and admissibility decisions) or by in-

${ }^{62}$ Hans, supra note 42, at 184-92; Vidmar, supra note 4, at 203-20; Shari Seidman Diamond et al., Juror Judgments about Liability and Damages: Sources of Variability and Ways to Increase Consistency, 48 DePaul L. Rev. 301, 311 (1998); Robert J. MacCoun, Differential Treatment of Corporate Defendants by Juries: An Examination of the "Deep-Pockets" Hypothesis, 30 Law \& Soc'y Rev. 121 (1996).

6.3 Jurors express concern about the impact of a high award on defendants. Edith Greene et al., The Effects of Injury Severity on Jury Negligence Decisions, 23 Law \& Hum. Behav. 675, 690 (1999). 
creasing the jury's active participation (through note taking and question asking). ${ }^{64} \mathrm{He}$ concludes that: "More active judges and more active juries inevitably lead to less power in the hands of the parties and their attorneys. These responses represent a weakening of adversarialism that is more fundamental."

Diamond and Vidmar's innovative study of jurors and insurance has already made an unprecedented contribution to our understanding of jury behavior and jury reform. I eagerly await the next installment.

${ }^{64}$ Joseph Sanders, Scientifically Complex Cases, Trial by Jury, and the Erosion of Adversarial Processes, 48 DePaul L. Rev. 355, 386 (1998).

${ }^{65}$ Id. at 387. 